\title{
Meso- and macrozooplankton composition patterns related to hydrodynamic structures in the Ligurian Sea (Trophos-2 experiment, April-June 1986)
}

\author{
Silvia Pinca ${ }^{1, *}$, Serge Dallot ${ }^{2}$ \\ 'I.S.A.M., 14 Corso Rainusso, I-16038 Sta Margherita Ligure, Italy \\ ${ }^{2}$ CNRS - URA 716, Station Zoologique, BP 28, F-06230 Villefranche-sur-Mer, France
}

\begin{abstract}
The distributional patterns of zooplanktonic fauna based on samples taken during the Trophos-2 cruise (spring 1986) in the western Liguro-Provençal Basin, Mediterranean Sea, are described. This region is permanently exposed to a cyclonic circulation with an associated thermohaline front which encloses a central divergence zone. In the middle of this central area, we encountered a mesoscale (about $70 \mathrm{~km}$ diameter) anticyclonic eddy. Taking into account the hydrological structure of the 0 to $200 \mathrm{~m}$ upper level, the area could be divided into 4 zones: (1) peripheral and frontal, (2) central Riviera, (3) central Corsica and (4) the eddy. These zones differed in the abundance of several zooplankton species. In particular, some of them showed a higher concentration in the eddy, such as the radiolarian Aulacantha scolymantha, the euphausiid calyptopis larvae, and the copepods Centropages typicus, Pleuromamma gracilis, Mesocalanus tenuicornis, Heterorhabdus papilliger and Euchirella rostrata. We suggest the central eddy is a favorable environment for these large species. Thus, increased primary and secondary production due to the influence of hydrodynamic phenomena appears not to be limited to the frontal zone. Within the eddy, zooplankton growth could be enhanced, thus favoring export production. To detect zooplankton species assemblages, the stations have been clustered into 5 groups based on their taxonomic composition and abundance. These groups had a rather good geographic coherence although they had a more complex distribution than the physical structure. This higher variability of spatial organization of the 5 plankton assemblages can be explained by behavioral and trophic phenomena.
\end{abstract}

KEY WORDS: Zooplankton · Hydrodynamics · Q-mode classification · MDS

\section{INTRODUCTION}

Numerous studies have demonstrated the regulation of planktonic ecosystems by physical oceanic processes (Denman \& Powell 1984, Legendre \& Demers 1984); the quality and intensity of this dependence is often strongly signaled in the spatial pattern of plankton biomass and species composition (Mackas et al. 1985). Clear examples of physical features which show an influence on the distributions of zooplankton and ichthyoplankton (e.g. concentration or

\footnotetext{
- Present address: c/o Mark Huntley, Scripps Institution of Oceanography, MBRD 0202, La Jolla, California 92093-0202,

USA.E-mail: spinca@ucsd.edu
}

dispersion, selection of organisms) are fronts and eddies

The Ligurian Sea (northwestern Mediterranean Sea) is a part of the Liguro-Provençal Basin (Gostan 1968), which includes the Provençal coasts, the French Riviera and the northwestern Corsican coasts. This region is characterized by the cyclonic Ligurian Current, whose geostrophic flow is induced by thermohaline variations (Béthoux et al. 1982) and influenced by winds and the particular orographic canalization of Atlantic water (Esposito \& Manzella 1982, Marullo et al. 1985).

The current organizes the hydrological structure of the basin into 3 main distinct zones: a coastal-peripheral zone, a frontal zone and a central zone (Boucher et 
al. 1987). The most well-known oceanographic feature in the basin is the Liguro-Provençal haline front, subject of many hydrographical and ecological studies since the early 1970 s (for a review on the subject see Sournia et al. 1990). Plankton studies have concentrated on the influence of the front on the horizontal and vertical distributions of different species and developmental stages of zooplankton organisms (Licot et al. 1983, Boucher 1984, Boucher et al. 1987, Ibanez \& Boucher 1987, Laval et al. 1989, Gorsky et al. 1991, Laval et al. 1992).

Nevertheless, this basic hydrological organization of the region may be complicated by other mesoscale structures: frontal meanders (Belluau et al. 1982, Sournia et al. 1990, Prieur et al. 1993), and mesoscale eddies in the central part of the basin and off the western and northern coasts of Corsica (Hela 1963 Stocchino \& Testoni 1978, Gasparini \& Manzella 1983 Marullo et al. 1985, Wald 1985, Taupier-Letage \& Millot 1986, Millot 1987). However, observations of zooplankton biomass and species composition in this central zone of the Ligurian Sea were not as numerous as in coastal and frontal zones; these observations were mainly acquired during occasional cruises (Razouls \& Thiriot 1973, De Bovée 1974, Goy \& Thiriot 1976). The results suggest that this central area is a highly productive zone in spring due to nutrient enrichment by strong vertical advective movements, and is an oligotrophic environment in summer (Gostan \& Nival 1967, Coste et al. 1972, Nival et al. 1972. Jacques et al. 1973, Nival et al. 1975, Finenko 1987).

In the present work the center of the basin was very well sampled most of the stations were situated in this zone. The aim of the study was to analyse the zooplankton species composition and to detect their heterogeneity in the whole area in relation to the particular hyctrodynamical structures. Therefore, we examined the distribution of mesozooplankton and macrozooplankton to find out whether and how the physical organization of the study area may influence (1) the distribution of the dominant zooplankton species and (2) the zooplankton community differentiation.

\section{MATERIALS AND METHODS}

Data collection. The research cruise Trophos-2 took place in the Ligurian Sea, western basin of the Mediterranean Sea, from April 4 to May 7, 1986. The studied area is situated between the French Riviera and Corsica. A total of 33 sampling stations were positioned along $4 \mathrm{NW}$ to SE transects perpendicular to the continental coast, cutting crosswise the Ligurian Current and the front. The distance between 2 successive stations was approximately $18 \mathrm{~km}$ (Fig. 1)
The cruise initially consisted of 2 legs, repeatedly sampling on the 33 station grid. However, the first leg was strongly disturbed by bad weather conditions. Therefore, the present work deals only with the samples taken during the second leg (April 22May 7).

Data collection included: (1) Hydrographic profiles $[\theta$ (temperature), $\mathrm{S}$ (salinity), $\mathrm{p}$ (pressure), $\mathrm{pH}, \mathrm{O}_{2}$ l, carried out from the surface to 600 or $800 \mathrm{~m}$ depth. The probe used was a CTDO (conductivity-temperature-depthoxygen, Guildline model 8705), calibrated before the mission. The measurements were recorded on magnetic tapes through a HP 9817 computer. (2) Chemical measurements (nutrients: $\mathrm{NO}_{2}, \mathrm{NO}_{3}, \mathrm{PO}_{4}, \mathrm{SiO}_{3}$ - only the results on nitrate concentration are reported here) and (3) Chlorophyll a (chl a), using water samples from Niskin bottles at 11 standard depths $(0,5,10,20,30,50$, $75,100,125,150$ and $200 \mathrm{~m}$ ). (4) Zooplankton samples were collected from vertical 200 to $0 \mathrm{~m}$ tows, using a triple net device: 1 WP2 standard net $\left(0.25 \mathrm{~m}^{2}\right.$ opening surface, $2.4 \mathrm{~m}$ of filtering length, $200 \mu \mathrm{m}$ mesh size) and 2 other WP2-like nets with mesh size of 50 and $500 \mu \mathrm{m}$ Each site was sampled several times. Zooplankton samples were fixed in $4 \%$ buffered formaldehyde until examination for species identification.

The physical-chemical data were used to obtain a hydrological description of the area surveyed. Horizontal maps (at the $50 \mathrm{~m}$ depth level to avoid influences by spring heating and dilution effects) and vertical sections along the 4 transects were traced for density excess, temperature and salinity fields, using

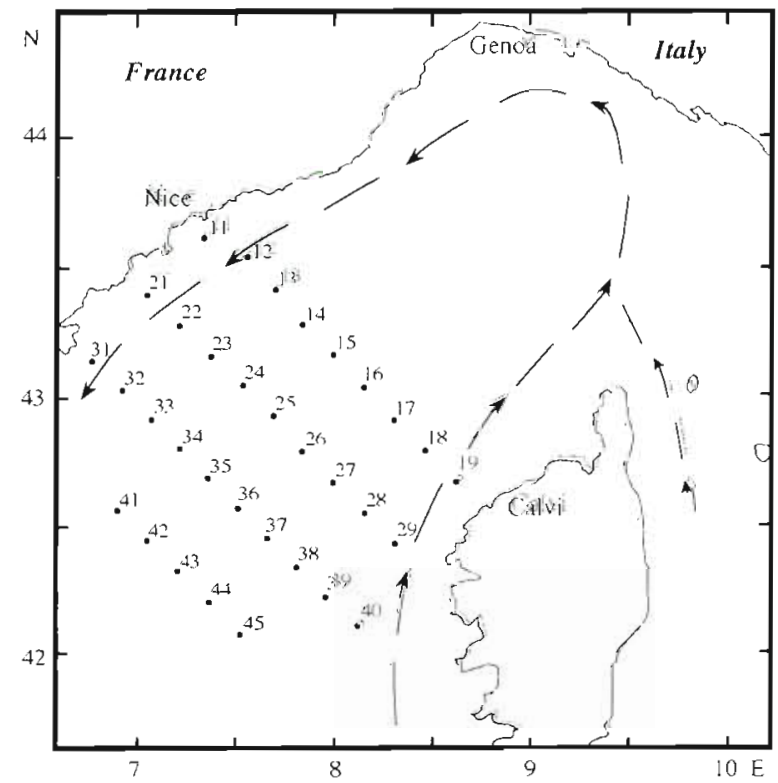

Fig. 1. Region studied of Trophos-2 (22 April to 7 May) and position of sampling sites. Arrows indicate current flow general direction 
the Unimap 2000 program $\left(\right.$ Uniras $^{\text {बi }}$ ) running on a HP 9000 computer

Since direct measurements of current speed and direction were not available, the evaluation of large and medium scale water motion was based on the computation of the geostrophic current component perpendicular to the transects (a near NE to SW direction). We calculated density excess and dynamic height to obtain the dynamic structure of the region, taking the $600 \mathrm{db}$ pressure as reference. We then calculated the geostrophic current speed values associated with the density anomalies

For each site, we examined zooplankton sample pairs coming from both the standard WP2 $200 \mu \mathrm{m}$ mesh net and from the $500 \mu \mathrm{m}$ mesh net. Each sample was divided into 2 equal parts using a Motoda box to be used for the taxonomic and abundance determination, and for the dry-weight determination for a biomass study respectively.

The taxonomic identification was mostly taken to the species level. In cases of suboptimal preservation, genus or family of the specimens were given. Different copepod developmental stages and siphonophores sexual phases were also distinguished. The samples used for taxonomic analysis were examined in toto, except for those species which were most abundant. In such cases, the species were counted within Motoda box subsample(s) to more than 40 specimens. Using this threshold for each taxon, the $95 \%$ probability confidence interval does not exceed the range $0.65 \mathrm{~N}$, $1.45 \mathrm{~N}$ ), where $\mathrm{N}$ is the estimated abundance value (Frontier 1972). For cases where the same taxa and developmental stages were present in both nets, we counted them in the net where they were more abundant in order to minimize under estimation from net avoidance and escape effects. The data collected were summarized for each station and taxon, as number of individuals $\mathrm{m}^{-3}$ (ind. $\mathrm{m}^{-3}$ ) of filtered sea water.

Data processing. To facilitate the interpretation of composition and abundance variations, we used different mathematical methods to group the stations on the grounds of taxa abundance data. The data were organized in a species-sites matrix. We removed the 'very rare' categories, i.e. those absent at $80 \%$ (or more) of the sampled sites. The abundance of the 40 remaining species were log-transformed to reduce the correlation between variance and mean and the influence of the most abundant species on Q-mode partial dissimilarity indexes (Clarke \& Green 1988).

Between-station dissimilarities were computed by the Orlóci's chord length metric (Orlóci 1978). We have chosen this particular distance coefficient after a preliminary study done comparing it with 2 other metrics, on log-transformed abundance data: Euclidean and Bray-Curtis' dissimilarity measures. The Orlóci's dis- similarity coefficient is the coefficient which best emphasized differences of abundances of both abundant and moderately abundant species.

A hierarchical agglomerative cluster analysis and a multidimensional scaling (MDS) ordination were used together (Field et al. 1982) to identify the faunal patterns of the sampling sites according to species composition and relative abundance. The 2 algorithms are computed from the same cord length dissimilarity matrix. The agglomeration method chosen for classification is the group-average sorting or arithmetic average clustering (Legendre \& Legendre 1979). We chose the multidimensional scaling method described by Shepard (1962) and Kruskal (1964) using the chord length matrix and selecting 3 final dimensions.

Once we had obtained the groups of stations, we screened for indicator species and environmental variables whose values differed the most between the computed groups of stations. We used several statistical tests (Sokal \& Rohlf 1981, Scherrer 1984) as exploratory data analysis tools, but only as a means to order species and environmental variables according to their between sample-groups contrasts (Field et al. 1982). The comparisons were done following 2 designs (Dallot et al. 1988): first, a test for clusters homogeneity followed by a search of the main contrasts between all cluster pairs; second, a search for the characteristic features of each cluster, contrasting to the remaining (unclustered) stations. Some appropriate tests were chosen according to the variable types, distribution properties, and group number. Later, we only considered the smallest computed probabilities corrected for multicomparison effects using Bonferroni adjustment (Wright 1992), and ranked in increasing order

The variables tested for the characterization of the groups included:

(1) The most frequent taxa abundance data, previously selected for cluster analysis, were considered as quantitative or ordered variables. Since the tested variables were used in the process of group forming, the tests lack statistical rigor (Field et al. 1982). According to the statistical properties of the variables, we used non-parametric tests: Kruskal-Wallis (K-W) and Wilcoxon-Mann-Whitney tests (W-M-W).

(2) The rarest taxa, which had been previously removed before the computation of the dissimilarity matrix, were considered as presence-absence data. The appropriate tests for analyzing the independence between stations classification and descriptor states are the $G$-test with William's correction (Williams 1976) and the Fisher's exact test.

(3) Several quantitative environmental variables were considered: surface temperature and salinity values; immersion of the $28.90 \mathrm{~kg} \mathrm{~m}^{-3}$ density excess isoline, an indicator of vertical movements of water 
masses; 0 to $200 \mathrm{~m}$ integrated nitrate concentration; and integrated ( 0 to 200 and 0 to $50 \mathrm{~m}$ ) chl a concentration values. We used here the same tests as in (1).

\section{RESULTS}

\section{Physical structure}

The analysis of the hydrological data allowed us to describe the main hydrodynamic structure of the region. We could find the 3 classical zones (Sournia et al. 1990): peripheral, frontal and divergence. In addition to this well-known hydrological organization, we recognised a mesoscale eddy in the very middle of the region.

Since the image obtained for the area surveyed was different from the normal picture, we schematically divided the region into 4 different zones, each of which was characterized by a particular hydrodynamic aspect. Vertical sections of density excess (Fig. 2A, B), horizontal maps of temperature, salinity and density excess (Fig. 3A, B, C), characteristic $\theta / S$ diagrams (Fig. 4), dynamic height maps (Fig. 5A, B), and geostrophic speed values were used to differentiate the hydrodynamic zones:

(1) The external zone (EZ) comprises the coastal and the frontal stations (Stns 11 to 13,21,31, 18 and 19), with isopycnal sloping towards the coast (Fig. 2A). In nearshore areas, usually defined as peripheral, the flow of the Ligurian and the Western Corsica Currents was identifiable by the maximum tilt of the 28.90 isopycnals, which indicates the highest current speeds. This area was characterized by warmer $\left(>13.20^{\circ} \mathrm{C}\right.$; Fig. $3 \mathrm{~A})$ and more diluted $(<38.20 \mathrm{~S}$; Fig. 3B) subsuperficial waters. The western Corsican coastal and offshore upper layer waters were more saline than the Riviera coastal waters, due to the absence of any conspicuous river discharges such as encountered along the Italian coast.

The 3 typical water masses are identifiable (Fig. 4), the Mediterranean Winter Water, MWW, characterized by its subsurface potential temperature minimum $\left(<13^{\circ} \mathrm{C}\right)$; the Levantine Intermediate Water (LIW), marked by the midwater acute maximum of both temperature and salinity; and the Mediterranean Deep Water (MDW) with lower salinity and potential temperature.

In the center of the region ( $C Z$ : central zone) we found the divergence, where all the isopleths were shallower than in the other zones (Fig. 2A). The typical dense water isopycnals $\left(\sigma_{t}>\right.$ $29.04 \mathrm{~kg} \mathrm{~m}^{-3}$ ) belonging to LIW reached here their most superficial layers ( $560 \mathrm{~m}$ ). In this area we observed the maximal values of salinity and density excess (Fig. 3B, C) and the lowest values of subsurface temperature minimum $\left(<13.00^{\circ} \mathrm{C}\right.$ at $50 \mathrm{~m}$; Fig. $\left.3 \mathrm{~A}\right)$.

The corresponding $\theta / \mathrm{S}$ diagrams of the stations belonging to this area were well separated in 2 geographic clusters (Fig. 4): in the southeast Corsican part of the $C Z$ the upper layer salinity was greater than the values observed in the Rivieran part 138.24 to 38.38 at $10 \mathrm{~m}$ deep, against 38.07 to 38.21 at the same depth). Accordingly, 2 subzones were separated:

(2) RCZ (Riviera Central Zone): Stns 14, 22, 23, 32 to 34; and

(3) CCZ (Corsica Central Zone): Stns 15 to 17,27 to 29,37 to $40,43,44$.

The $\theta / \mathrm{S}$ diagrams of both subzones exhibit evidence of subsuperficial mixing between LIW and MDW.

Between the peripheral and central regions we found the presence of the thermohaline fronts, defined by strong horizontal gradients of both salinity and density excess (Fig. 3B, C).

(4) Between the 2 central subzones, the core of the anticyclonic eddy (AE) was located (Stns 24 to 26, 35, $36,41,42)$, with a near $70 \mathrm{~km}$ diameter and $300 \mathrm{~m}$
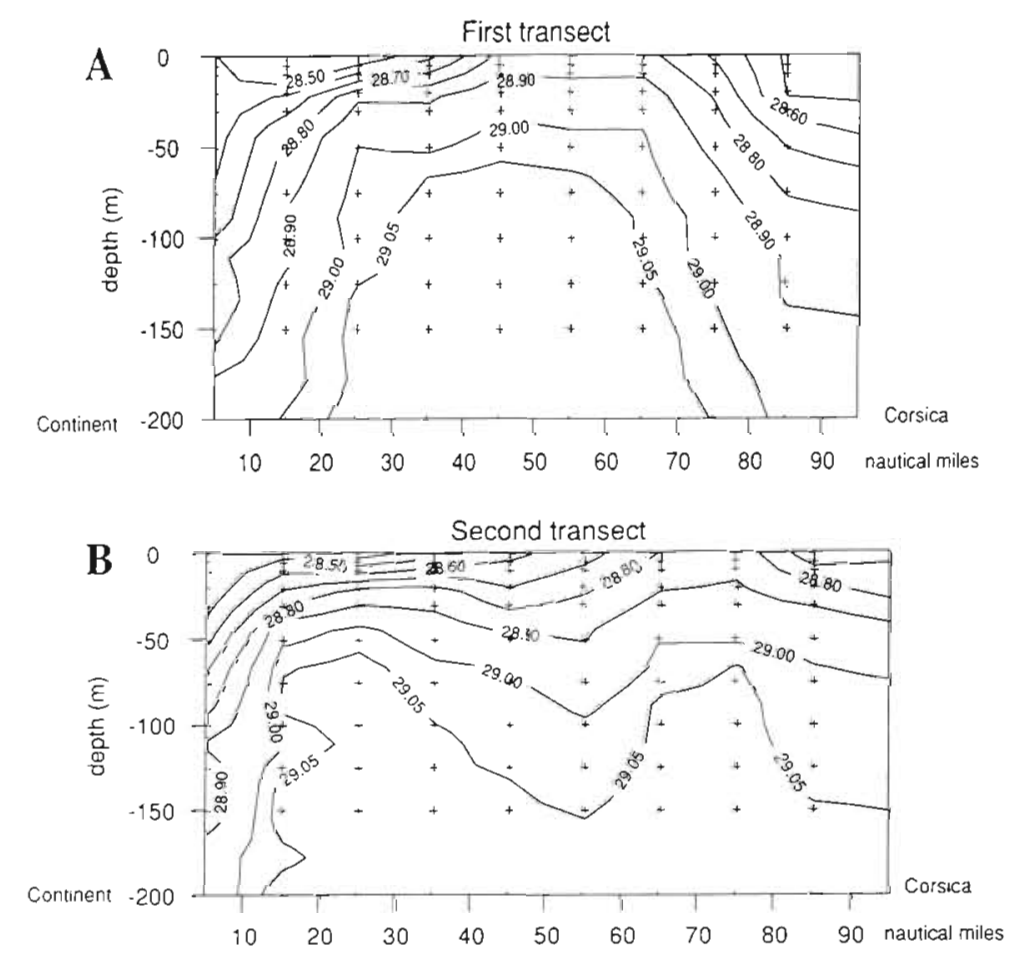

Fig. 2. Density excess $\left(\mathrm{kg} \mathrm{m}^{-3}\right)$ along the $(A)$ first and $(B)$ second transects showing an anticyclonic eddy 

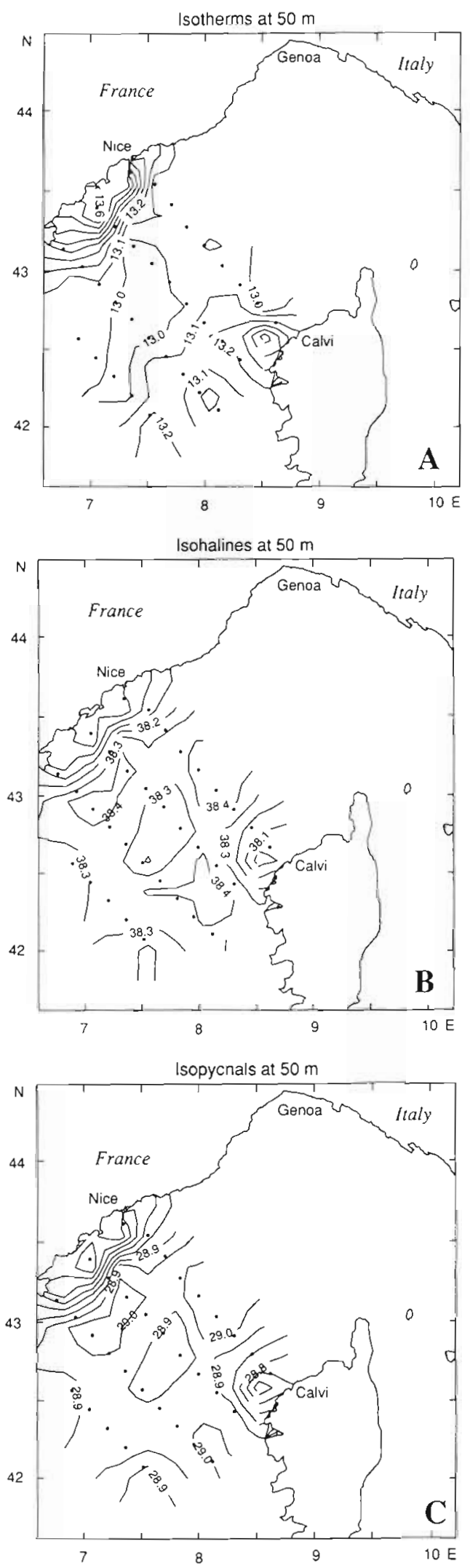

Fig. 3. Horizontal maps of $(\mathrm{A})$ temperature $\left({ }^{\circ} \mathrm{C}\right)_{;}$(B) salinity; and $(C)$ density excess $\left(\mathrm{kg} \mathrm{m}^{-3}\right)$

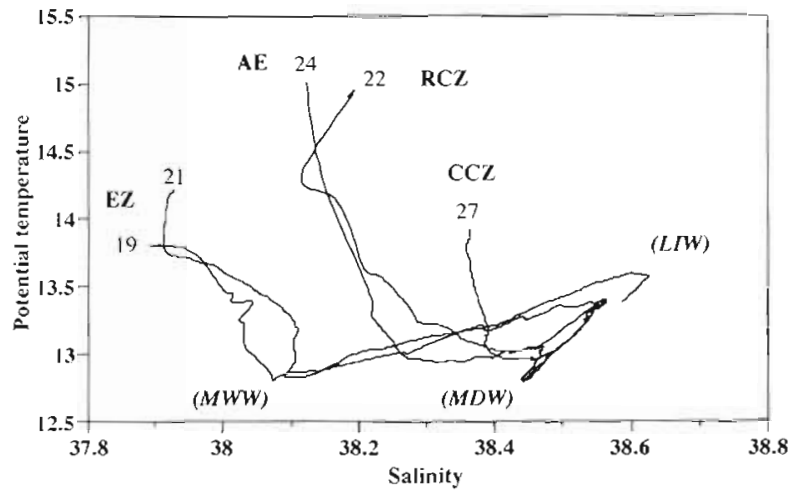

Fig. 4. Potential temperature $\left({ }^{\circ} \mathrm{C}\right) /$ salinity diagrams for some selected stations of the 4 hydrological zones: EZ: external zone: Stns 21, Riviera and 19, Corsica; RCZ: Riviera coastal zone; AE: anticyclonic eddy; and CCZ: Corsica coastal zone. Position of type waters: MWW: Mediterranean Winter Water; LIW: Levantine Intermediate Water, and MDW: Mediterranean Deep Water

depth. Compared with the first transect (Stns 11 to 19) (Fig. 2A), the II (Stns 21 to 29) and III (Stns 31 to 40) transects (Fig. $2 \mathrm{~B}$ for second transect) clearly showed a maximum $100 \mathrm{~m}$ deepening in the $\mathrm{S}$ and $\sigma_{i}$ isopleths. At the depth of $50 \mathrm{~m}$, the AE is marked by a core of low salinity $(<38.30)$ and low density excess $\left(<28.95 \mathrm{~kg} \mathrm{~m}^{-3}\right)$, surrounded by more saline (>38.40) and dense water $\left(>29.00 \mathrm{~kg} \mathrm{~m}^{-3}\right.$ ) (Fig. 3B, C). In this zone, dynamic height (in dynamic millimetres, dyn mmj maximum values (Fig. 5B; absolute maximum 38 dyn $\mathrm{mm}$ at $\operatorname{Stn} 26$ ) were observed within a ring of low values (minimum 17 dyn mm, Stn 15). The computed SW to NE geostrophic current component exceeded $12 \mathrm{~cm} \mathrm{~s}^{-1}$, to be compared to the cyclonic current of $40 \mathrm{~cm} \mathrm{~s}^{-1}$ maximum velocity. This AE was also found during the first leg at 70 to $90 \mathrm{~km}$ off Cap Camarat (southwestern part of the survey, Fig. 5A) with similar features. The AE displacement during the 2 legs occurred in a SW to NE direction at a speed close to $2 \mathrm{~km} \mathrm{~d}^{-1}$ (Fig. 5A, B). It was approaching the first radial (Stn 14) at the end of the survey (May 5).

The $\theta / \mathrm{S}$ diagrams of the AE stations (Fig. 4) are marked by the presence of a subsurface nearly isothermal cold layer (upper level: 34 to $63 \mathrm{~m}$; deeper level: 60 to $103 \mathrm{~m} ; \theta$ : 12.95 to $13.01^{\circ} \mathrm{C}$ ) with salinity increasing with depth. These features suggest that such a structure was formed during the preceding winter by subduction of a surface water mass of the $\mathrm{CZ}$ or EZ zone. Stn 45, our southernmost station, also shows a high dynamic height and a $\theta / \mathrm{S}$ diagram similar to those observed within the $\mathrm{AE}_{i}$ therefore it probably belongs to a similar anticyclonic structure. Even if this station was well separated geographically from the $A E$ it was included in this hydrodynamic group. 

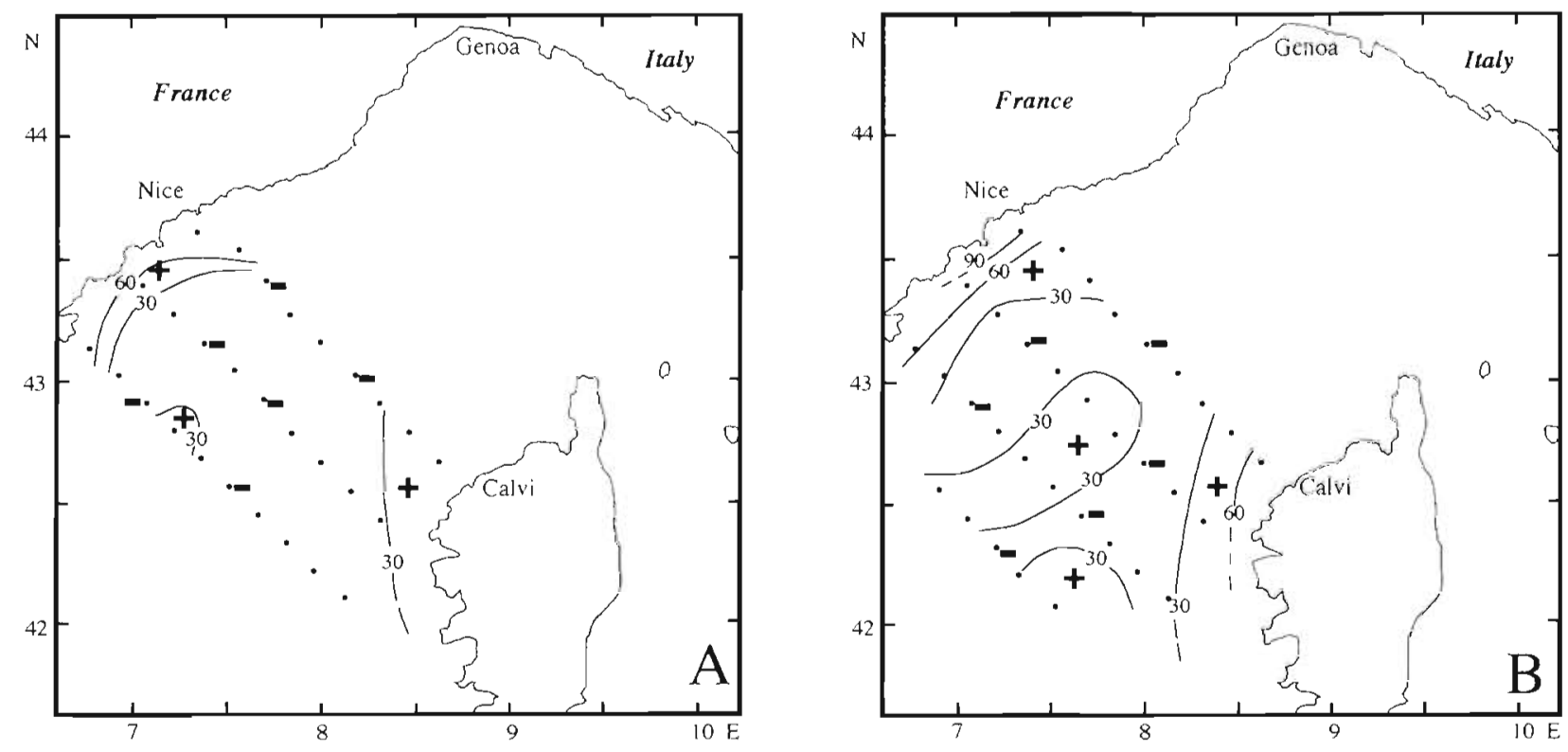

Fig. 5. $30 \mathrm{db}$ dynamic height (in dyn mm) referenced to $600 \mathrm{db}$ level of no motion. (A) First leg (April 5 to 19); (B) second leg (April 22 to May 7). '+' and ' - ' indicate respectively the highest and lowest dynamic height values along each transect
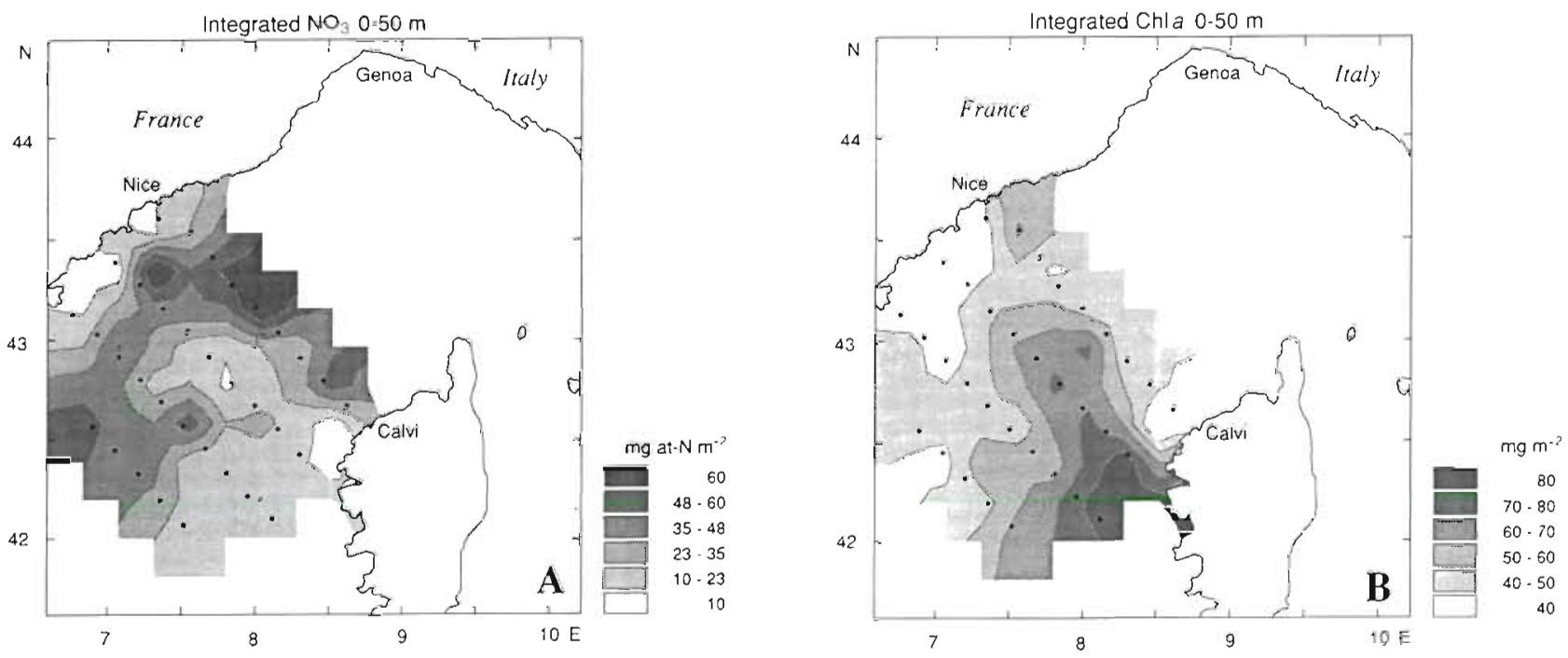

Fig. 6. (A) $\mathrm{NO}_{3}$ and chl a (B) 0 to $50 \mathrm{~m}$ integrated values

\section{Non-conservative parameters in relation to the physical structure}

The upper level of the euphotic layer was not entirely nitrate depleted. The $1 \mu \mathrm{M} \mathrm{N}^{-1}$ isopleth was generally situated between 30 and $50 \mathrm{~m}$ depth Coastal stations were the exceptions, especially near Corsica where nitrate values were the lowest. The horizontal nitrate variability of the upper layer is better shown in the 0 to $50 \mathrm{~m}$ integrated map (Fig 6A): the highest values are in the northern stations, while minimal values appear in the southeastern Corsican region. The tongue-like area of low values $(<20 \mu \mathrm{M}$ $\mathrm{N} \mathrm{m}^{-2}$ ) corresponds to a similar structure of peak 0 to $50 \mathrm{~m}$ integrated chl a values area $\left(>60 \mathrm{mg} \mathrm{m}^{-2}\right.$, up to a maximum of $80 \mathrm{mg} \mathrm{m}^{-2}$; Fig. $6 \mathrm{~B}$ ). Therefore, the integrated nitrate map appears as an inverse plot of integrated chl a for most of the survey area. However, these images do not follow the concentric structure of salinity and density excess (Fig. 3B, C), but correspond better with the temperature signature (Fig. 3A). 
The highest depth-specific values of chl a were found in frontal zones, between 20 and $30 \mathrm{~m}$ depth. The highest concentration in absolute terms was found off western Corsica: $4.11 \mathrm{mg} \mathrm{m}^{-3}$ at $20 \mathrm{~m}$ at $\mathrm{Stn} 39$. Off the Riviera, chl a concentration reached its maximum at $\mathrm{Stn} 13$ at $20 \mathrm{~m}\left(3.13 \mathrm{mg} \mathrm{m}^{-3}\right)$. High values (>2 $\mathrm{mg}$ $\mathrm{m}^{-3}$ ) were also recorded in more central stations, where a stronger stratification was present in comparison with adjacent zones.

On the whole $200 \mathrm{~m}$ upper layer, the nitrate isopleths followed the isopycnal structure corresponding to the divergence structure fairly well. We could recognize lower concentrations in the $\mathrm{EZ}\left(<3 \mu \mathrm{M} \mathrm{N} \mathrm{l}^{-1}\right.$ at $\left.100 \mathrm{~m}\right)$ compared to higher values in the central area, i.e. in the $\mathrm{CZ}$ and at some $\mathrm{AE}$ stations (>3 $\mu \mathrm{M} \mathrm{N}^{-1}$ at $\left.100 \mathrm{~m}\right)$. The highest concentration values $\left(>7 \mu \mathrm{M} \mathrm{N}^{-1}\right)$ did not clearly coincide with the isopycnal pattern. Some shallow high nitrate values were observed within the $\mathrm{AE}$ and in the RCZ of Transect I.

\section{Zooplankton populations}

\section{General variations}

The total abundance of zooplankton was strongly variable among stations. The highest values were found in the coastal zones, or at the border between the external and the divergence zone. The absolute maximum was recorded at Stn 12 (almost 2000 ind. $\mathrm{m}^{-3}$ ), and concentrations over 1000 ind. $\mathrm{m}^{-3}$ were found at $\operatorname{Stn} 45,23,29$, and 31 . The minimum value was recorded at Stn 28 (less then 50 ind. $\mathrm{m}^{-3}$ ). Along the first transect we observed an increase in abundance towards the center. However, along the other transects the abundance decreased in the center.

A total of 138 different taxa were found, with the 55 copepod taxa accounting for $70 \%$ of the total density. Among them, Centropages typicus, Clausocalanus spp. (the smaller Clausocalanus $S$, including $C$. pergens, $C$. paululus, $C$. jobei, and the larger Clausocalanus $B$, including $C$. furcatus and $C$. arcuicornis), and the copepodites of the 2 genera Paracalanus and Clausocalanus spp. were the most abundant (mean values around 300 ind. $\mathrm{m}^{-3}$ ). Other abundant groups include radiolarians, here present with the potentially carnivorous species Aulacantha scolymantha, euphausiids, siphonophores and finally appendicularians, constituting altogether $99 \%$ of the remaining specimens after exclusion of the copepods. Gelatinous macrozooplankton, either herbivorous (salps) or carnivorous groups (medusae and chaetognaths), was scarce (Table 1).

The spatial distribution of the relative abundance of the different taxa showed large variations (Fig. 7). A higher relative abundance of siphonophores (Mug- giaea atlantica) and appendicularians was observed in the EZ. In the central stations there was a higher relative abundance of radiolarians, while the pteropod molluscs were important only in the CCZ. The euphausiids were somewhat abundant in the central region, especially in the middle of the second transect (within the AE) where we also observed a siphonophores abundance decrease.

\section{Variations related to the zones}

Significant variations of abundances were found among the different hydrodynamic zones for 12 taxa ( $\mathrm{K}-\mathrm{W}$ test, Table 2): the euphausiid calyptopis larvae, the radiolarian Aulacantha scolymantha, the siphonophore Lensia conoidea, the copepods: Euchirella rostrata (adults and copepodites), Centropages typicus, Nannocalanus minor, Mesocalanus tenuicornis, Heterorhabdus papilliger, Pleuromamma gracilis, Euchaeta acuta, Clausocalanus $B$.

The comparisons of abundance values between the EZ and both the RCZ and CCZ gave significant results (multiple comparison tests, Table 2). The abundance in the EZ was always lower than in the other 2 zones, except for Nannocalanus minor which was more abundant in the $\mathrm{EZ}$ than in the CCZ. However, the direct comparisons between the CCZ and RCZ were never significant.

The comparisons between the AE and some other zones were significant for 11 taxa. Density in the AE was higher than in the CCZ, or RCZ and/or EZ, except for Euchaeta acuta, which was more abundant in the $\mathrm{CCZ}$ than in the AE. Among the taxa which showed the contrast between the AE and the other groups, 3 taxa (calyptopis, Heterorhabdus papilliger and Nannocalanus minor) gave significant response to the comparisons between the $\mathrm{AE}$ and the surrounding subzones, without showing contrast between the $\mathrm{CZ}$ and the $\mathrm{EZ}$.

\section{Faunistic grouping}

The grouping analysis was done on the selected 40 taxa. Ordination analysis gave a structurally similar configuration (Fig. 8A, B) to the clustering technique (Fig. $8 \mathrm{C}$ ); the results of the classification were therefore considered acceptable. We obtained 5 groups of stations, the most evident characteristic of which was to exhibit a particular geographic disposition as well.

Two heterogeneous groups are clearly distinguishable from the dendrogram (Fig. $8 \mathrm{C}$ ) and the first MDS (Fig. 8A; stress $=0.06$ ): the first group is constituted of 5 stations and is referred to as Group C. It is topographically well-defined, being formed by adjacent central stations (AE, CCZ and RCZ). The second group 
Table 1. Mean (ind. $\mathrm{m}^{-3}$ ); standard deviation (SD) and relative frequency $(f)$ of presence of the different taxa in the whole collection. Categories are listed as decreasing mean abundance order. Bold taxa are those selected for the cluster analysis. cop.: copepodites; furc.: furcilia; eud.: eudoxid phase; pol : polygastric colonies

\begin{tabular}{|c|c|c|c|c|c|c|c|}
\hline Taxa & Mean & $\mathrm{SD}$ & $f$ & & Mean & $\mathrm{SD}$ & $f$ \\
\hline Copepods & 1272.7 & 414.6 & 1.0 & $\begin{array}{l}\text { Clausocalanus S } \\
\text { Paracalanus/Clausocalanus cop. } \\
\text { Centropages typicus } \\
\text { Centropages typicus cop. } \\
\text { Calanidae cop. } \\
\text { Oithona helgolandica/nana } \\
\text { Oithona spp. cop. } \\
\text { Paracalanus spp. } \\
\text { Calocalanus styliremis/contractus } \\
\text { Clausocalanus B } \\
\text { Ctenocalanus vanus } \\
\text { Euchirella rostrata } \\
\text { Pleuromamma gracilis } \\
\text { Euchirella rostrata cop. } \\
\text { Ctenocalanus vanus cop. } \\
\text { Acartia clausi } \\
\text { Mesocalanus tenuicornis } \\
\text { Oncaea spp. } \\
\text { Acartia clausi cop. } \\
\text { Euchaeta acuta cop. } \\
\text { Oithona plumifera/setigera } \\
\text { Scolecithricella spp. } \\
\text { Heterorhabdus papilliger } \\
\text { Neocalanus gracilis } \\
\text { Eucalanus spp. } \\
\text { Heterorhabdus papilliger cop. } \\
\text { Pleuromamma abdominalis cop. } \\
\text { Pleuromamma abdominalis } \\
\text { Pleuromamma gracilis cop. } \\
\text { Nannocalanus minor } \\
\text { Euchaeta acuta }\end{array}$ & $\begin{array}{r}305.4 \\
303.0 \\
213.5 \\
168.0 \\
45.0 \\
42.4 \\
36.5 \\
32.8 \\
19.1 \\
16.0 \\
13.7 \\
13.4 \\
12.5 \\
11.4 \\
10.3 \\
5.1 \\
4.5 \\
3.2 \\
2.4 \\
2.1 \\
1.8 \\
1.8 \\
1.0 \\
1.0 \\
0.6 \\
0.6 \\
0.5 \\
0.5 \\
0.4 \\
0.4 \\
0.4\end{array}$ & $\begin{array}{r}268.2 \\
249.9 \\
139.5 \\
176.5 \\
51.0 \\
33.4 \\
23.5 \\
29.8 \\
12.0 \\
10.0 \\
7.4 \\
8.3 \\
6.9 \\
10.2 \\
7.3 \\
3.9 \\
3.5 \\
7.3 \\
2.8 \\
1.5 \\
1.6 \\
0.9 \\
0.7 \\
0.9 \\
0.5 \\
0.5 \\
0.3 \\
0.4 \\
0.3 \\
0.4 \\
0.3\end{array}$ & $\begin{array}{l}1.0 \\
1.0 \\
1.0 \\
1.0 \\
1.0 \\
1.0 \\
1.0 \\
1.0 \\
1.0 \\
1.0 \\
1.0 \\
1.0 \\
1.0 \\
1.0 \\
1.0 \\
1.0 \\
1.0 \\
0.9 \\
1.0 \\
1.0 \\
1.0 \\
1.0 \\
1.0 \\
1.0 \\
1.0 \\
0.9 \\
0.9 \\
0.9 \\
0.8 \\
0.8 \\
0.9\end{array}$ \\
\hline $\begin{array}{l}\text { Radiolarians } \\
\text { Appendicularians }\end{array}$ & 7.2 & 13.6 & 0.4 & Aulacantha scolymantha & 12.8 & 9.5 & 1.0 \\
\hline Euphausiids & 5.0 & 4.9 & 1.0 & $\begin{array}{l}\text { Calyptopis } \\
\text { Meganyctiphanes norvegica furc. }\end{array}$ & $\begin{array}{l}4.1 \\
0.3\end{array}$ & $\begin{array}{l}4.6 \\
0.3\end{array}$ & $\begin{array}{l}1.0 \\
0.9\end{array}$ \\
\hline Siphonophores & 3.2 & 5.6 & 1.0 & $\begin{array}{l}\text { Lensia conoïdea eud. } \\
\text { Chelophyes appendiculata eud. } \\
\text { Chelophyes appendiculata pol. } \\
\text { Abylopsis tetragona eud. } \\
\text { Lensia conoidea pol. }\end{array}$ & $\begin{array}{l}0.8 \\
0.8 \\
0.1 \\
0.4 \\
0.3\end{array}$ & $\begin{array}{l}0.8 \\
2.0 \\
0.1 \\
0.3 \\
0.4\end{array}$ & $\begin{array}{l}0.8 \\
0.9 \\
0.6 \\
0.9 \\
0.8\end{array}$ \\
\hline Other Crustacea & 1.5 & 4.8 & 0.8 & Phronima sedentaria juv. & 08 & 4.6 & 0.1 \\
\hline Molluscs & 0.6 & 0.6 & 0.9 & Cavolinia inilexa & 0.5 & 0.6 & 0.9 \\
\hline Polychaets & 0.5 & 0.6 & 0.3 & Pelagobia longocirrhata & 0.1 & 0.2 & 0.3 \\
\hline Thaliacea & 0.5 & 0.7 & 0.4 & Salpa fusiformis & 0.2 & 0.5 & 0.3 \\
\hline Medusae & 0.3 & 0.5 & 0.8 & Solmissus albescens & 0.1 & 0.2 & 0.8 \\
\hline Chaetognaths & 0.1 & 0.1 & 0.7 & Sagitta minuma & 0.04 & 0.08 & 0.30 \\
\hline Fishes & 0.1 & 0.1 & 0.3 & & & & \\
\hline Decapods & 0.1 & 0.1 & 0.3 & Brachiura larvae & 0.02 & 0.04 & 0.12 \\
\hline
\end{tabular}

is formed by 3 coastal stations. In the MDS representation Stn 21 is rather far from the other 3 stations, and also in the dendrogram it appears isolated and closer to nongrouped stations. Rather than letting it constitute a group alone, we chose to associate it with Stns 11, 12 and 13 for its geographical position. They constitute the Group A comprising the Riviera coastal stations.

A second ordination (Fig. 8B, stress $=0.10$ ) was executed after the elimination of the 9 stations belonging to Groups $\mathrm{A}$ and $\mathrm{C}$. This allowed us to obtain a clearer image of the remaining sites, which showed a high similarity among them. Both the MDS and the dendro- 
First transect

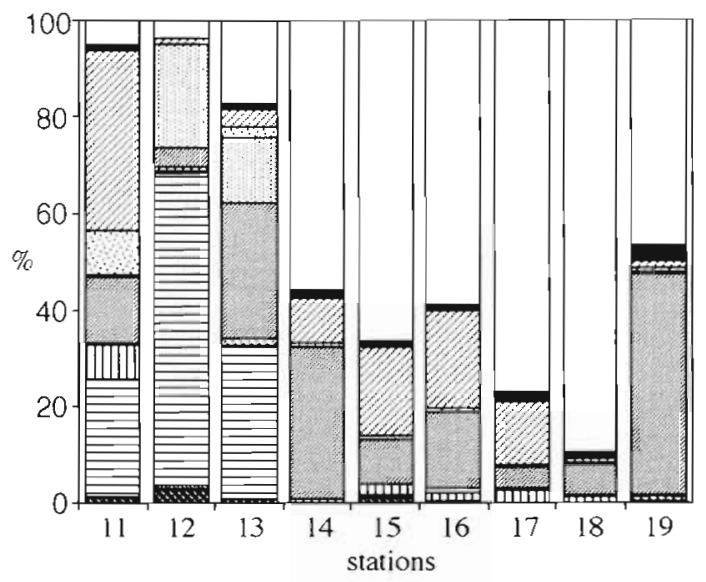

Second transect

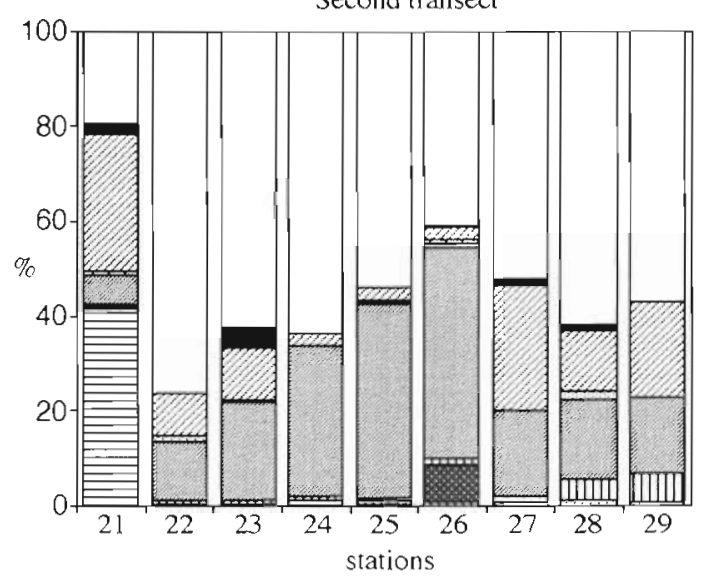

Third transect
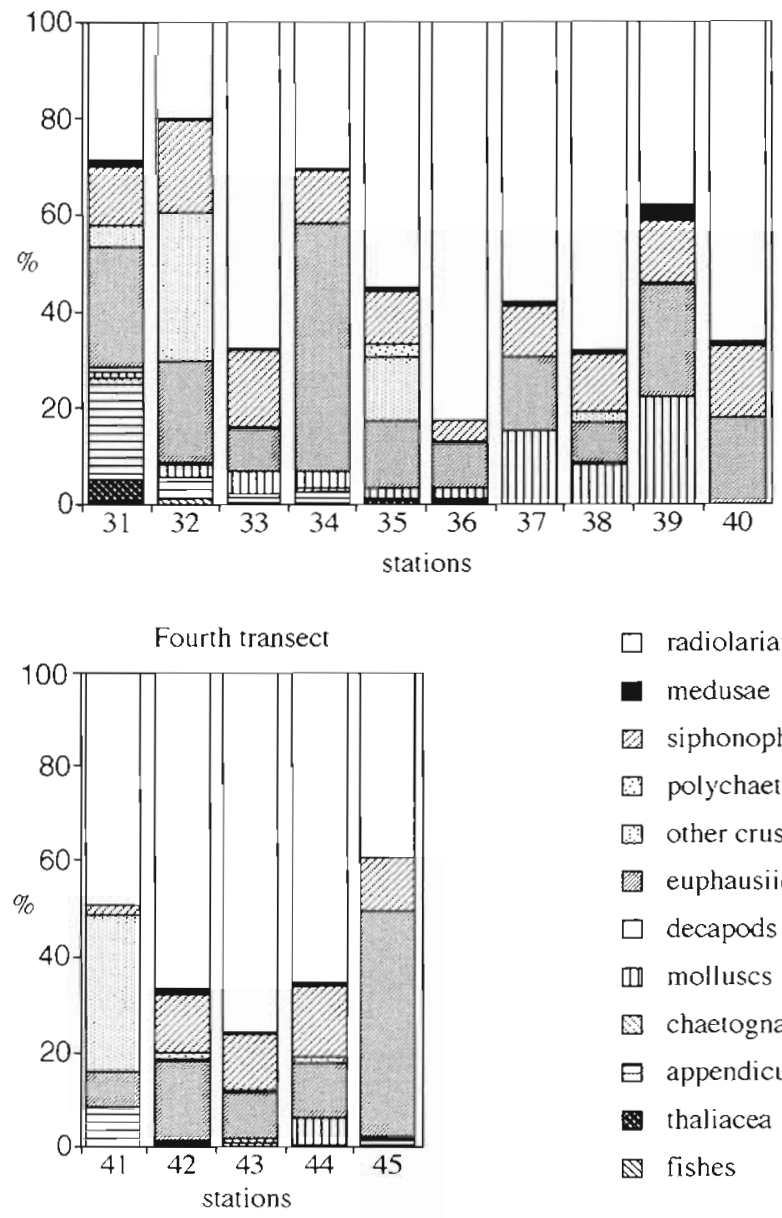

$\square$ radiolarians

- medusae

siphonophores

3 polychaetes

[i] other crustaceans

留 euphausiids

$\square$ decapods

(II) molluses

8 chaetognaths

$\boxminus$ appendicularians

: thaliacea

fishes

Fig. 7. Relative abundance variations of the different groups of taxa along each transect. Percentages are calculated without considering copepods

gram provided descriptions of the structure of 3 groups. The first Group B is composed of 7 stations, rather dispersed over the whole region. They are central stations plus one belonging to the AE (Stn 35). The remaining 2 groups are more similar to one another, as we can deduce from the dendrogram. Group $D$ is constituted of 6 eastern stations, of the CCZ and Corsican EZ. As Group B, Group E is more heterogeneous, being formed by stations which are dispersed over the whole area, either central, coastal and within the AE.

Stations sampled in the day did not show any particular features in comparison to the others.

\section{Characterization of the most typical physical properties of each group}

The groups are constituted of sites with similar faunistic characteristics (species composition and abundances) and are associated with particular environ- mental and taxonomic parameters. The environmental descriptors which turn out to be important to the specification of the groups since they vary significantly (K-W test) among them are: surface temperature and salinity, depth of the $28.90 \mathrm{~kg} \mathrm{~m}^{-3}$ isopycnal, and 0 to 50 and 0 to $200 \mathrm{~m}$ integrated chl a concentrations. According to a posteriori multiple comparisons between pairs, Groups A, B and D are distinguished by significant salinity values. Groups $D$ and $E$ are not significantly different, however the $Z$ associated probabilities ( $Z=$ auxiliary variable in the multiple comparison test) for $S, \theta$ and depth of $28.90 \mathrm{~kg} \mathrm{~m}^{-3}$ isopycnal are not $>0.2$; we can conclude that they are probably distinguishable from a hydrological point of view.

Finally, we characterized the ecological properties synthetically describing each group versus all other stations (W-M-W test; Table 3). Group A is represented by low salinity values: this group includes stations close to the coast, situated in the diluted waters of the Ligurian Current. Group B shows characteristic high salinity val- 

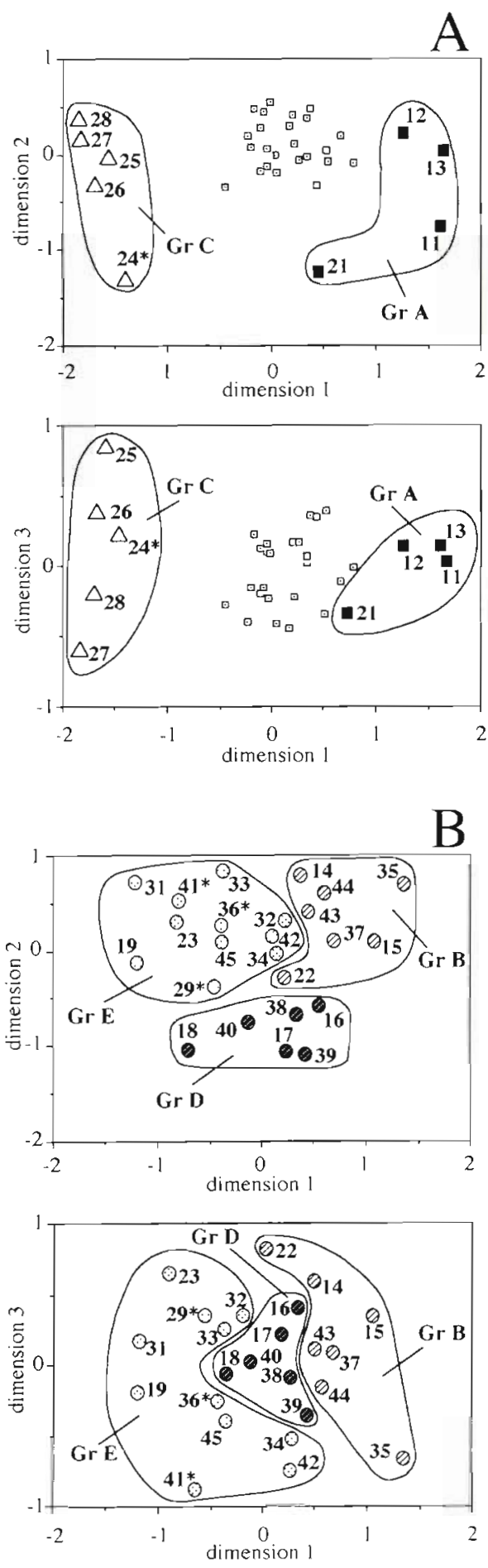

ues, typical of divergence waters; Group $\mathrm{C}$ shows high integrated chl a values; Group D is marked by high salinity, Like the previous group, and by shallow depths of the $28.90 \mathrm{~kg} \mathrm{~m}^{-3}$ isopycnal, indications of an area of divergence; Group $E$ is characterized by high temperature and low salinity values and by a deep immersion of the $28.90 \mathrm{~kg} \mathrm{~m}^{-3}$ isopycnal: all these properties are typical of a coastal environment of diluted and warm waters.

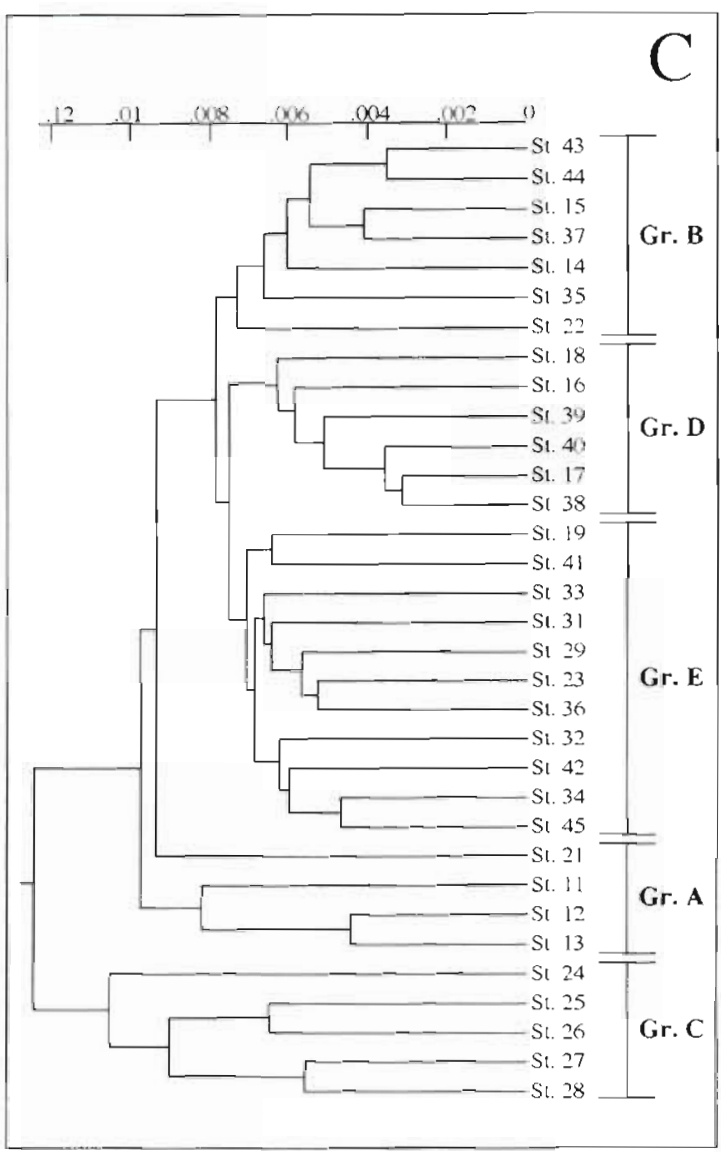

Fig. 8. Representations of MDS ordinations and classification of the 33 stations grouped according to the abundance of the most frequent taxa. *Daytime samples. A: first 3-dimension MDS. The 2 groups $A$ and $C$ are already evident. B: second 3dimension MIDS. The other 3 Groups $(B, D, E)$ appear after elimination of the 9 stations constituting Groups $A$ and $C$. C: dendrogram and resulting clusters (chord length distance and group average sorting)

\section{Faunistic composition of the groups}

The taxonomic descriptors which determined the characterization of each group were found in a similar way We obtained a list of 16 among the most abundant taxa showing significant among-groups $\mathrm{K}$-W tests. These are categories with high abundances and ubiquitous presence in the whole study area. The most significant cases 
Table 2. Selected taxa showing significant variations of abundance among the 4 hydrodynamical zones (EZ: external zone, RCZ: Riviera central zone, CCZ: Corsica central zone, AE: anticyclonic eddy). $\mathrm{p}_{\mathrm{K} \text {-w: }}$ associated probability of the Kruskal-Wallis test. Significant associated $p$-values for multiple comparison tests (pairs of groups): $0.001 \leq p<0.01$; ${ }^{*} p<0.001$. Median values of abundance are given for each group as number of specimens $\mathrm{m}^{-3}$

\begin{tabular}{|c|c|c|c|c|c|c|c|c|c|}
\hline Taxa & $p_{K-W}$ & $E Z>$ & $\mathrm{RCZ}>$ & $A E>$ & $\mathrm{CCZ}>$ & $E Z$ & $\mathrm{RCZ}$ & $\mathrm{AE}$ & $\mathrm{CCZ}$ \\
\hline Euchirella rostrata cop. & 0.0001 & & & $\mathrm{RCZ} \cdot \mathrm{EZ} \cdot$ & $\mathrm{EZ} \cdot$ & 2.6 & 4.2 & 21.2 & 12.4 \\
\hline Calyptopis & 0.0002 & & & $\mathrm{CCZ} \cdot \cdot$ & & 2.6 & 2.9 & 8.4 & 0.8 \\
\hline Centropages typicus & 0.0013 & & $\mathrm{EZ} \cdot$ & E.Z. & $\mathrm{EZ} \cdots$ & 25.3 & 245.3 & 193.4 & 293.2 \\
\hline Euchirella rostrata & 0.002 & & EZ $\cdots$ & EZ. & EZ $\cdots$ & 4.1 & 18.4 & 15.7 & 13.9 \\
\hline Nannocalanus minor & 0.004 & $\mathrm{CCZ}^{\circ}$ & & $\mathrm{CCZ}^{\cdot}$ & & 0.7 & 0.2 & 0.4 & 0.1 \\
\hline Aulacantha scolymantha & 0.005 & & & $\mathrm{EZ} \cdot \mathrm{CCZ} \cdot \cdot$ & & 7.0 & 10.1 & 21.1 & 7.5 \\
\hline Mesocalanus tenuicornis & 0.009 & & & $\mathrm{CCZ}^{\cdot}$ & $E Z^{\cdot}$ & 1.4 & 3.7 & 4.2 & 5.5 \\
\hline Lensia conoïdea & 0.020 & & & $\mathrm{EZ} \cdot$ & & 0.1 & 0.2 & 0.6 & 0.3 \\
\hline Heterorhabdus papilliger & 0.040 & & & $\mathrm{RCZ}^{*}$ & & 0.8 & 0.6 & 1.6 & 0.7 \\
\hline Pleuromamma gracilis & 0.040 & & & $\mathrm{EZ} \cdot$ & $\mathrm{EZ} \cdot$ & 6.4 & 10.7 & 13.7 & 13.4 \\
\hline Clausocalanus $B$ & 0.047 & & & & $\mathrm{EZ} \cdot$ & 8.0 & 12.3 & 15.4 & 19.3 \\
\hline Euchaeta acuta & 0.047 & & & & $\mathrm{AE} \cdot$ & 0.2 & 0.4 & 0.2 & 0.6 \\
\hline
\end{tabular}

Table 3. Environmental differences among the 5 groups. Scheme for the variation of median values of the physicochemical parameters in the 5 groups. $\uparrow($ or $\downarrow$ ) indicates that the parameter shows a significantly higher (or lower) median value in the specified group than in the others. Bold values are the probabilities associated to the Wilcoxon-Mann-Whitney's test (specified group vs all other stations). S: salinity; $\theta$ : temperature

\begin{tabular}{|c|c|c|c|c|c|c|c|c|c|}
\hline \multirow{2}{*}{$\begin{array}{l}\text { Parameters } \\
\mathrm{S}_{0 \mathrm{~m}}\end{array}$} & & A & & B & $\begin{array}{c}\text { Groups } \\
\text { C }\end{array}$ & & $\mathrm{D}$ & & $E$ \\
\hline & 37.89 & $0.001 \downarrow$ & 38.26 & $0.002 \uparrow$ & 38.17 & 38.29 & $0.017 \uparrow$ & 38.13 & $0.003 \downarrow$ \\
\hline$\theta_{0 \mathrm{~m}}$ & 14.17 & & 14.86 & & 14.03 & 14.05 & & 14.98 & $0.008 \uparrow$ \\
\hline Depth $\sigma t=28.90$ & 137 & & 27 & & 29 & 21 & $0.020 \downarrow$ & 41 & $0.018 \uparrow$ \\
\hline Chl $a_{0-50 \mathrm{~m}}$ & 39.3 & & 45.1 & & $66.8 \quad 0.001 \uparrow$ & 57.7 & & 41.8 & \\
\hline Chl a $0-200 \mathrm{~m}$ & 52.7 & & 69.6 & & $101.1 \mathbf{0 . 0 1 4} \uparrow$ & 84.3 & & 61.2 & \\
\hline
\end{tabular}

for a posterioricomparisons between pairs of groups are: (1) Centropages typicus (adults) for the comparison between $A$ and $B, A$ and $C, C$ and $E_{;}(2)$ Oithona plumiferasetigera; (3) Euchirella rostrata (adults and copepodites); and (4) Ctenocalanus vanus (copepodites), which are the most important categories in the comparison between $A$ and $C$. The 2 opposed Groups $A$ and $C$ also constitute the pair with the highest number of taxa with significant relative density heterogeneity.

Subsequently, we identified the taxa which could be considered the most characteristic for each ecological community (Table 4), i.e. those with a significantly higher density in comparison with the assemblage of the other environments. The community of Group $A$ is characterized by 3 taxa, constituted of small neritic copepods which were more abundant in this group than in the others: Oithona plumifera-setigera (adults), Oncaea spp. (adults), Ctenocalanus vanus (copepodites). Group B does not show significant differences of abundance. Group $C$ is marked by 5 taxa with higher abundances: Centropages typicus (adults), Euchirella rostrata (adults and copepodites), Pleuromamma gracilis (adults), Clausocalanus B. Group D is characterized by higher abundances of Calanidae copepodites. Group E shows higher density of copepodites of Acartia clausi.

Concerning the less abundant taxa, we can say that the most characteristic species are those which show an associated probability $\leq 0.1$, for either $G$ or Fisher's exact tests, Table 4. Group $\mathrm{A}$ is characterized by the higher quantity of taxa: 3 species of medusae (Rhopalonema velatum, the most significant species, Euphysa aurata and Phialidium hemisphaericum), the appendicularian Oikopleura albicans, the coastal siphonophore Muggiaea atlantica and 4 copepods. Group $C$ is marked by the copepodites of Eucalanus spp. Group D is characterized by the siphonophore Chelophyes appendiculata. Group E by fishes (larvae and Cyclothone braueri), the appendicularian Fritillaria pellucida and the medusae Solmissus albescens.

\section{DISCUSSION}

The Ligurian Sea zooplankton has been extensively studied during the last decade, following the increasing interest in differential distribution patterns across frontal boundaries. In the Mediterranean Sea previous 
Table 4. Identification of the characteristic taxonomic descriptors of the 5 groups of stations. Differences in abundance of most abundant taxa between each group and the whole stations: cases with $p \leq 0.05$ associated to the Wilcoxon-Mann-Whitney's test $\left(\mathrm{p}^{\prime}\right.$ w.M.M $)$. Bold values indicate higher medians in the single group compared to the rest of groups. Frequency of presence of less abundant taxa: the list follows a decreasing order of importance of the taxa in the characterization of the groups, i.e. a probability values increasing order for $G$-test $\left(p_{C}^{\prime}\right)$ and Fisher's exact test $\left(p_{F}^{\prime}\right)$. Bold values indicate higher frequencies in the single group compared to the rest of groups. Probability values associated to the tests are corrected with the Bonferroni adjustment for simultaneous inference. $\mathrm{df}=1$

\begin{tabular}{|c|c|c|c|c|c|c|}
\hline & Taxa & Group & Groups & $\mathrm{P}^{\prime}$ W.M-W & $\mathrm{p}_{G}^{\prime}$ & $\mathrm{p}_{\mathrm{F}}^{\prime}$ \\
\hline & & A & $B, C, D, E$ & & & \\
\hline \multirow[t]{6}{*}{ Most abundant } & Centropages typicus & 4.21 & 7.49 & 0.01 & & \\
\hline & Oithona plumifera/setigera & 2.99 & 1.1 & 0.01 & & \\
\hline & Oncaea spp. & 4.09 & 0.77 & 0.01 & & \\
\hline & Euchirella rostrata cop. & 0.91 & 3.68 & 0.02 & & \\
\hline & Ctenocalanus vanus cop. & 4.32 & 3.16 & 0.02 & & \\
\hline & Euchirella rostrata & 2.16 & 4.04 & 0.03 & & \\
\hline \multirow[t]{10}{*}{ Least abundant } & Rhopalonema velatum & 0.09 & 0.03 & & 0.005 & \\
\hline & Oikopleura albicans & 0.09 & 0.03 & & 0.005 & \\
\hline & Temora stylifera & 0.09 & 0.06 & & 0.02 & \\
\hline & Haloptilus acutifrons & 0.03 & 0.3 & & 0.02 & \\
\hline & Candacia armata & 0.12 & 0.79 & & & 0.02 \\
\hline & Euphysa aurata & 0.06 & 0.03 & & 0.10 & \\
\hline & Phialidium hemisphaericum & 0.06 & 0.03 & & 0.10 & \\
\hline & Muggiaea atlantica & 0.06 & 0.03 & & 0.10 & \\
\hline & Labidocera wollastoni & 0.06 & 0.03 & & 0.10 & \\
\hline & & $\mathrm{C}$ & $A, B, D, E$ & & & \\
\hline \multirow[t]{10}{*}{ Most abundant } & Clausocalanus S & 3.48 & 7.95 & 0.003 & & \\
\hline & Centropages typicus & 10.98 & 7.21 & 0.003 & & \\
\hline & Centropages typicus cop. & 4.02 & 7.03 & 0.003 & & \\
\hline & Oithona spp. cop. & 2.89 & 5.19 & 0.02 & & \\
\hline & Euchirella rostrata & 5.37 & 3.71 & 0.02 & & \\
\hline & Euchirella rostrata cop. & 6.19 & 2.99 & 0.02 & & \\
\hline & Pleuromamma gracilis & 4.8 & 3.3 & 0.02 & & \\
\hline & Oithona plumifera/setigera & 0.66 & 1.45 & 0.04 & & \\
\hline & Ctenocalanus vanus cop. & 1.64 & 3.38 & 0.04 & & \\
\hline & Clausocalanus $B$ & 5.02 & 3.48 & 0.04 & & \\
\hline \multirow[t]{2}{*}{ Least abundant } & Eucalanus spp. cop. & 0.15 & 0.21 & & & 0.03 \\
\hline & & $D$ & $A, B, C, E$ & & & \\
\hline \multirow[t]{2}{*}{ Most abundant } & Calyptopis & 0.53 & 1.91 & 0.004 & & \\
\hline & Calanidea cop. & 7.05 & 4.09 & 0.01 & & \\
\hline \multirow[t]{2}{*}{ Least abundant } & Chelophyes appendiculata & 0.18 & 0.67 & & & 0.10 \\
\hline & & $E$ & $A, B, C, D$ & & & \\
\hline \multirow[t]{2}{*}{ Most abundant } & Acartia clausii cop. & 1.97 & 0.91 & 0.01 & & \\
\hline & Euchaeta acuta & 0.25 & 0.65 & 0.03 & & \\
\hline \multirow[t]{3}{*}{ Least abundant } & Fishes & 0.18 & 0.06 & & 0.05 & \\
\hline & Fritillaria pellucida & 0.15 & 0.06 & & 0.10 & \\
\hline & Solmissus albescens & 018 & 058 & & 0.10 & \\
\hline
\end{tabular}

works concerned distributional studies of specific taxonomic groups, mainly to characterize basin differences (Furnestin 1968) and coastal to offshore faunistic gradients. Although the main faunistic contrast between near coast Ligurian plankton and offshore 'divergence' plankton is known and related to hydrological structure and primary productivity level (Goy \& Thiriot 1976), detailed studies arose only from the co-occurring development of intensive continuous multiparametric probing and sampling techniques of the upper level of the sea and of the sophisticated data analysis methods (Boucher 1984, Boucher et al. 1987, Ibanez \& Boucher 1987, Boucher 1988, Fromentin et al. 1993).

Among a vast bulk of work concerning small-scale horizontal daytime distribution of zooplankton organisms, 2 important categories of results emerged.

(1) Abundance variability of each species may show intense small-scale patchiness, even changing among their successive developmental stages. This arises from complex behavioural, feeding and reproductive 
strategies in response to environmental organization. This topic was particularly well illustrated by Boucher (1988) for the copepod Calanus helgolandicus.

(2) Community patterns of surface zooplankton appear consistently linked to hydrological singularities, whatever the season and the physical characteristics of the upper layer, and even disconnected from the typical frontal organization below the thermocline. The space dependent associations correspond to the positions of hydrodynamic regions induced by the secondary circulation cells of the Ligurian Current.

In the present study, we focused on the distribution patterns of fauna sampled during Trophos-2 (1986), a cruise which covered the whole Liguro-Provençal Basin. The grid of stations was chosen expressly to cover the whole region between the French Riviera and Corsica, comprising the 2 parts of the LiguroProvençal front - usually studied independently and the central region - usually less sampled compared to the several small-scale studies on the front itself. The choice of the spatial dimensions proved to be adequate to detect mesoscale structures and to study the interactions between hydrodynamics and planktonic community organization.

Another important new aspect of this study is that the whole community of zooplankters sampled by the applied nets (200 and $500 \mu \mathrm{m}$ mesh size) was taken into account, retaining then all the minor taxa which are less abundant than the prevailing copepod group, but which nevertheless are important components of the ecosystem, including predatory species. The samples were taken during night to be able to sample the vertical migrating species which rejoin the euphotic layer community only during darkness.

The observation of a particular physical aspect of the region allowed us to investigate the biological-dynamical interactions between hydrodynamic structures and zooplankton populations. We aimed at linking the observations of the 2 compartments, both with an a posteriori comparison of the biological and physical structures (variation of species abundance among 4 hydrographic zones), and synoptically (grouping).

The presence of an anticyclonic current in the middle of the Liguro-Provençal Basin had previously been detected during the Hydrokor cruises (Anonymous 1973, 1975), and during the Trophos-1 cruise. This structure was observed from vertical profiles of density excess, in the first case, and from a horizontal anticyclonic displacement of the ship and drifting buoys off the $2000 \mathrm{~m}$ bathymetric, during Trophos- 1 .

We have no data on the history of the eddy observed during Trophos-2 (its formation, geographic origin, or age). We thus cannot fully understand the causes of a particular differentiation of this water mass under the influence of the cyclonic circulation, in comparison with the other water masses. The eddy could have been formed by instability processes of the Ligurian coastal current or of atmospheric forcings, and could have subsequently departed to the open sea. Similar formation mechanisms are suggested for other (cyclonic or anticyconic) eddies in the Ligurian Basin by Hela (1963), Gasparini \& Manzella (1983), Marullo et al. (1985), Taupier-Letage \& Millot (1986), and Millot (1987). These last authors described the central zone of the basin during the February-March season as subject to strongest mesoscale activity and linked to the production of cold MWW. Our oceanographic data showed the presence of a nearly isothermal subsurface cold layer inside the eddy, which probably can be taken as an indication of the formation of this structure during the preceding winter in the surface layer of the frontal zone, particularly in its marginal part where salinity is higher.

The hydrographic analysis shows that, despite a variety of physical-chemical gradients, the area can be schematically divided into 4 separated water bodies: $\mathrm{EZ}, \mathrm{RCZ}, \mathrm{AE}$ and $\mathrm{CCZ}$. Understanding the ecological aspect of this already complex physical situation becomes harder when we consider the 2 following matters.

First we have to consider that the cruise was carried out during spring, when important changes in the environmental conditions take place: beginning stratification as an effect of warming, along with the fertilization of the shallow layers supplied by the vertical advections promote and maintain algal development. The chl a richest zones are at the boundary between divergence and periphery (in our EZ), i.e. in the frontal region where nutrient vertical advection is conspicuous (Sournia et al. 1990). High values are also recorded in the center, where upper layer stabilization is evident. Another mechanism which can be used to explain the high chl a value observed even inside the AE is deeper winter mixing in the core, as suggested for warm core eddies in the Levantine Basin (Krom et al. 1993).

Second, the cruise took place during a relatively short period during this rapid development of environmental conditions. Consequently, the ecological description that we obtained is simply a momentary image of a complex and rapidly evolving situation. Moreover, when we try to explain the causes of some observed effects through the relations between the physical aspect and the biological components, we sometimes encounter difficulties when the effects are the result of the interaction of both the physical aspects and the biological components. This appears clearly in the instance of nutrients. The vertical profiles of nitrate concentrations are somehow related to the deep water ascent due to the advective movements, but since they 
do not act as a conservative parameter, there is a lack of correspondence with the dynamic structure somewhere.

Notwithstanding these difficulties of interpretations, we could answer to our 2 main questions. (1) The physical structure of the basin, which in this study is complicated by a mesoscale eddy, has an influence on abundances of zooplankters. Several species showed in fact significant variations of abundance in the 4 hydrodynamic zones described a priori. (2) An ecosystem structuration in different faunistic communities does exist, and these communities are both rather coherent from a geographic point of view and in some cases related to the hydrologic features.

The hydrodynamic partitioning of the region has, thus, an accordance with the distributions of the organisms. The 4 hydrodynamic zones can not only be described from a hydrodynamical and hydrological point of view but they also show characteristic contrasts of abundances of species. In this context, the AE is particularly interesting because it appears as a region where large copepods (adults and larvae), juvenile stages of euphausiids, predatory siphonophores and potentially predatory radiolarians are more concentrated than in the surrounding $\mathrm{CCZ}$ and RCZ. In particular, the copepodites which were more abundant here than in the other zones belonged to the species Euchirella rostrata. Boucher (1984), studying the distributions of some copepod populations through the Liguro-Provençal front, explained the higher concentration of copepodites of this species in the front during high primary production periods as a consequence of the favourable condition of this localization to the development of the species. Similarly, here we can think of the presence of more advantageous conditions for reproduction of Euchirella rostrata in the $\mathrm{AE}$, offered by a richer algal concentration. This can also be true for the calyptopis larvae, which belong mainly to the species Meganyctiphanes norvegica, an abundant euphausiid generally found in the center of the Ligurian Basin (Goy \& Thiriot 1976, Ibanez \& Boucher 1987). This large species is a prey for some planktivorous fishes and whales. These observations suggest a confirmation of Owen's assertion (1981) on the behaviour of a stationary eddy as a 'reproductive refuge' for certain micronektonic organisms (Euphausia pacifica). Moreover, several studies confirmed that both cores of warm-core eddies (Bradford et al. 1982) and rings have a characteristically enhanced primary productivity (Tranter et al. 1980). We indeed found a higher integrated chl $a$ in the AE community. The preference of the larval stages for the AE and the higher abundance of the relatively large and carnivorous-omnivorous copepods Mesocalanus tenuicornis, Heterorhabdus papilliger and Pleuromamma gracilis, along with the carnivorous Lensia conoidea and Aulacantha scolymantha suggest that there is a strong production which can sustain the presence of juveniles and high trophic level species.

The signature of the physical structure over the biological component is also evident in the agreement, even if partial, between the a priori defined zones and the faunal organization. After examining the regional heterogeneity of species composition of zooplankton communities (Mackas \& Sefton 1982), in order to discriminate different 'faunal zones' (Fasham \& Angel 1975), we found relations between the faunistic characteristics and the particular hydrologic structure. Generally, the zooplankton communities show a similar typology to the physical aspect, even if they are characterized by a stronger complexity of geographic organization. The patterns of zooplankton distribution in fact partially coincide with the a priori division, but they do not simply repeat the concentric structure of the hydrodynamic zones. This result is probably connected to different productivities inside the 4 zones. Moreover, it is easier to understand why only partial coincidence was obtained if we consider that the analysis of each single population distribution as a function of a physical division gives results inevitably different from the study of whole population communities, since the latter originate essentially from interspecific relationships and behaviours.

The faunal group which has the most central location and which coincides fairly well with the AE is similarly characterized by higher concentrations of phytoplankton. It shows a typical open sea faunistic structure, with mesopelagic, prevalently herbivorous copepods, namely Clausocalanus arcuicornis and C. furcatus -2 halophilous species already found in high abundances in the CZ (Mazza 1967). Along with these species other characteristic taxa of the group are larger, some vertically migrating, and carnivorous-omnivorous copepods, such as Pleuromamma gracilis, Centropages typicus, Clausocalanus $B$ and Euchirella rostrata. This last species was more abundant in the central stations even in the simultaneous Italian cruise in the Gulf of Genoa (Zunini-Sertorio et al. 1990).

The faunal group located in the northwestern area corresponds in part to the Riviera stations of the EZ. It is well defined from a physicochemical point of view, its characteristics being clearly dissimilar to the other environments. Salinity is lower than in the other faunal groups. This is the parameter which best describes the variations among water masses of different origins in the Liguro-Provençal front (Ibanez \& Boucher. 1987) and, similarly, in this study it appears to be the physical descriptor which characterizes the main differences in most of the classes of stations, together with temperature, a critical parameter under the direct influence of 
the spring warming effects, and chl a. The characteristic species assemblage of this group is typical of an ecologically mature coastal environment, exploiting the productive richness of a coastal region and the particular fertility of a frontal area. It is composed by herbivorous and filter-feeding (small epipelagic copepods and appendicularians - Oikolpeura albicans), and omnivorous and carnivorous species (small copepods, small medusae, the coastal siphonophore Muggiaea atlantica). Most of these taxa (Oncaeidae, Temora stylifera and meroplanktonic components as Phialidium hemisphaericum) have already been recognised as neritic (Mazza 1967, Boucher et al. 1987), or more abundant in the peripheral or coastal zone of the Liguro-Provençal front region (Goy \& Thiriot 1976, Seguin \& Dallot 1989).

The sites of the faunal community located along the northward Corsican Current correspond well to part of the $\mathrm{CZ}$ (but comprise also 1 station of the EZ). In agreement with this position, the stations are characterized by high salinity. The community is constituted of herbivorous copepodites, including as most representatives the juveniles of Calanidae.

The community of the group which is composed of stations mostly situated in the western part, off the Provençal coasts, but belonging to 4 zones, reflects the temperature condition appearing at the end of the cruise: the increased surface temperatures are probably one of the explanations of the differences of this population in comparison with the others. The characteristic species of this community are juveniles of the herbivorous copepod Acartia clausi and the appendicularian Fritillaria pellucida.

The similarity between the oceanographic picture and the zooplankton organization in different assemblages suggests some spatial autocorrelation (Mackas \& Sefton 1982, Mackas 1984) of the plankton community constitution over a mesoscale space (some tens of kilometres). We can interpret the community pattern and its apparent spatial correlation with the hydrodynamic scheme as evidence of the influence of the vertical structure of the environment on the community structure (Ashjian \& Wishner 1993): advection controls production and consequently local species composition. However, the biological variability represented by all groups of samples together bears evidence of other causes for the organization of plankton into several communities. The hydrodynamic forces and the hydrological gradients lead to a spatial differentiation of the planktonic ecosystem, but the more complex. structure of the latter is also derived from primary production effects and from trophic and other purely behavioral relations. As Ashjian \& Wishner (1993) suggested in the case of species distribution across the Gulf Stream, food and niche competition and preda- tion, along with the spatial diversity of the physical environment are all probable regulating mechanisms for the observed community structures

\section{CONCLUSION}

The present comparative study of the physical aspect of mesoscale features and of the faunistic organization of zooplankton communities showed the ecological importance of mesoscale eddies in the Mediterranean Sea. Similar features and responses of organisms to them have been described for other regions of the oceans, even if the spatial scales were not always comparable.

The approach consisting of a complementary set of numerical techniques applied in the study of this eddy appears to be very promising. It allowed us to detect the particular faunal compositions related to the geographic location and, in certain cases, to the hydrodynamic structures. Previuos studies of the influence of eddies on zooplankton distribution or behavioural responses focused on few a priori selected species. We think that both the physical-biological coupling demonstrated here and the methodology used open the way for a deeper understanding of the ecological aspect of eddies, with regard to the other components of the trophic network which are involved in the system.

Acknowledgements. The Trophos-2 cruise was organised by the GDR P4, CNRS, INSU and realised as part of the program France-JGOFS (Frontal). The work is a part of S.P.'s PhD thesis, realised as a cooperation between the University of Genoa (Italy) and the Station Zoologique of the University of Paris VI, in Villefranche-sur-Mer (France). We thank L. Prieur for the help concerning geostrophic current calculations, J. Dolan, $M$. Karner and the 3 anonymous reviewers for their suggestions and the correction of the manuscript.

\section{LITERATURE CITED}

Anonymous (1973) Résultals des campagnes du N-O Korotneff, 1969-1971 CEROV, Résultats d'observation, 5, Station Zoologique, Villefranche-sur-Mer

Anonymous (1975) Résultats des campagnes du N-O Korotneff, 1972-1973. CEROV, Résultats d'observation, 16, Station Zoologique, Villefranche-sur-Mer

Ashjian CJ, Wishner KF (1993) Temporal persistence of copepod species groups in the Gulf Stream. Deep Sea Res 40: $483-516$

Belluau M, Blanc F, Coste B (1982) Structures hydrologiques à petite échelle dans la zone de divergence de la Mer Ligure (Méditerranée nord-occidentale): étude par l'analyse en composantes principales de séries spatio-temporelles multiples. Mar Biol 70:283-293

Béthoux JP, Prieur L, Nyffeler F (1982) The water circulation in the north-western Mediterranean sea, its relation with 
wind and atmospheric pressure. In: Nihoul JCJ (eds) Hydrodynamics of semi-enclosed seas. Elsevier, Amsterdam, p 129-142

Boucher J (1984) Localization of zooplankton populations in the Ligurian marine front: role of ontogenic migration. Deep Sea Res 31(5):469-484

Boucher J, Ibanez F, Prieur L (1987) Daily and seasonal variations in the spatial distribution of zooplankton populations in relation to the physical structure in the Ligurian Sea front. J mar Res 45:133-173

Boucher J (1988) Space-time aspects in the dynamics of plankton stages. In: Rothschild BJ (ed) Toward a theory on biological-physical interactions in the world oceans. Kluwer Academic, Amsterdam, p 203-214

Bradford JM, Heath RA, Chang FH, Hay CH (1982) The effect of warm-core eddies on oceanic productivity off northeastern New Zealand. Deep Sea Res 29 (12A) $1501-1516$

Clarke KR, Green RH (1988) Statistical design and analysis for a 'biological effects' study. Mar Ecol Prog Ser 46 $213-226$

Coste B, Gostan J, Minas H (1972) Influence des conditions hivernales sur les productions phyto- et zooplanctoniques en Méditerranée nord-occidentale. I. Structures hydrologiques et distribution des sels nutritifs. Mar Biol 16 $320-348$

Dallot S, Goy J, Carré C (1988) Peuplements de carnivores planctoniques gélatineux et structures productives en Méditerranée occidentale. In: Minas HJ, NivalP (eds) Océanographie méditerranéenne. Oceanol Acta (Spec Issue): 193-209

De Bovée F (1974) Influence des conditions hivernales sur l'écologie des copépodes planctoniques de Méditerranée nord-occidentale: campagne Mediprod I $2^{\text {eme }}$ partie, 4-16 avril 1969) Vie Milieu 24(1B):109-140

Denman KL, Powell TM (1984) Effects of physical processes on planktonic ecosystems in the coastal ocean. Ocean Mar Biol A Rev 22:125-168

Esposito A, Manzella G (1982) Current circulation in the Ligurian Sea. In: Nihoul JCJ (ed) Hydrodynamics of semienclosed seas. Elsevier, Amsterdam, p 187-203

Fasham MJR, Angel MV (1975) The relationship of the zoogeographic distributions of the planktonic ostracods in the northeast Atlantıc to the water masses. J mar biol Ass UK 55:739-757

Field JG, Clarke KR, Warwick RM (1982) A practical strategy for analysing multispecies distribution patterns. Mar Ecol Prog Ser 8:37-52

Finenko ZZ (1987) Effect of winter conditions upon phytoplankton production in north-western parts of the Mediterranean Sea. 2e Coll. Franco-Soviétique. Yalta IFREMER Actes Colloq 5:11-22

Fromentin JM, lbanez F, Legendre P (1993) A phytosociological method for interpreting plankton data. Mar Ecol Prog Ser 93:285-306

Frontier S (1972) Calcul de l'erreur sur un comptage de zooplankton. J exp mar Biol Ecol 8:121-132

Furnestin ML (1968) Le zooplancton de la Méditerranée (bassin occidental). Essai de synthèse. J Cons int Explor Mer 32(1):25-69

Gasparini GP, Manzella GMR (1983) A possible eddy generating mechanism in the Ligurian basin. Appl Math Modelling 7:291-294

Gorsky G, Lins da Silva N, Dallot S, Laval P, Braconnot JC, Prieur L (1991) Midwater tunicates: are they related to the permanent front of the Ligurian Sea (NW Mediterranean)? Mar Ecol Prog Ser 74:195-204
Gostan J (1968) Contribution à l'étude hydrologique du bassin Lıguro-Provençal entre la Riviera et la Corse. Thèse Doc Etat, Fac Sci, Université de Paris

Gostan J. Nival P (1967) Relations entre la distribution des phosphates mineraux dissous et la répartition des pigments dans les eaux superficielles du golfe de Gênes. Cah Océanogr 19:41-52

Goy J, Thıriot A (1976) Conditions estivales dans la divergence de Méditerranée nord-occidentale. II. Macroplancton et micronecton. Etude qualitative et estimation quantitative des cnidaires et des euphausiacés. Ann Inst Oceanogr 52(1):33-44

Hela I (1963) Surface current in the Ligurian Sea. Bull Inst océanogr Monaco 60(1268):1-15

Ibanez F, Boucher J (1987) Anisotropie des populations zooplanctoniques dans la zone frontale de Mer Ligure. Oceanol Acta 10(2):205-216

Jacques G, Minas HJ, Minas M, Nival P (1973) Influence des conditions hivernales sur les productions phyto- et zooplanctoniques en Méditerranée Nord-Occidentale. II. Biomasse et production phytoplanctonique. Mar Biol 23: $251-265$

Krom MD, Brenner S, Kress N, Neori A, Gordon LI (1993) Nutrient distributions during an annual cycle across a warm-core eddy from the Eastern Mediterranean Sea. Deep Sea Res 40(4):805-825

Kruskal JB (1964) Multidimensional scaling by otpimising goodness of fit to a non-metric hypothesis. Psychometrika 29:1-27

Laval P, Braconnot JC, Carré C, Goy J, Morand P, Mills CE (1989) Small-scale distribution of macroplankton and micronekton in the Ligurian Sea (Mediterranean Sea) as observed from the manned submersible Cyana. J Plankton Res 11:665-685

Laval P, Braconnot JC, Lins da Silva N (1992) Deep planktonic filter-feeders found in the aphotic zone with the Cyana submersible in the Ligurian Sea (Western Mediterranean). Mar Ecol Prog Ser 79:235-241

Legendre L, Demers S (1984) Towards dynamic biological oceanography and limnology. Can J Fish Aquat Sci 41: $2-19$

Legendre L, Legendre P (1979) Masson SA (ed) Ecologie numérique. Presses de l'Université du Québec, Paris

Licot M. Gaspar A, Hecq JH (1983) Distribution du plancton au niveau du front Liguro-Provençal au large de la Corse Résultats préliminaires des campagnes Trophos 1982. Rapp P-v Réun Cons int Explor Mer 28 (9):213-214

Mackas DL (1984) Spatial autocorrelation of plankton community composition in a continental shelf ecosystem. Limnol Oceanogr 29 (3):451-471

Mackas DL, Denman KL, Abbot MR (1985) Plankton patchiness: biology in the physical vernacular. Bull mar Sci 37(2) $652-674$

Mackas DL, Sefton HA (1982) Plankton species assemblages off southern Vancouver Island: geographic pattern and temporal variability. J mar Res 40 (4):1173-1200

Marullo S, Salusti E, Viola A (1985) Observations of a smallscale baroclinic eddy in the Ligurian Sea. Deep Sea Res 32(2):215-222

Mazza J (1967) Les copépodes pélagiques en Méditerranée occidentale. Développement post larvaire. Biologie. Ecologie. Thèse de Doctorat de $3^{\text {tme }}$ cycle, Université de Paris

Millot C (1987) The structure of mesoscale phenomena in the Ligurian Sea inferred from the DYOME experiment. A Geoph 5B (1):21-30

Momzikoff A, Dallot S, Pizay MD (1992) Blue and yellow fluorescence of filtered seawater in a frontal zone 
(Ligurian Sea, northwest Mediterranean Sea). Deep Sea Res 39 (9): 1481-1498

Nival P, Malara G, Charra R, Nival S, Palazzoli I (1972) Evolution annuelle des biomasses de phytoplancton et de zooplancton dans la Mer Ligure. C r Acad Sc, Paris 275: $1295-1298$

Nival P, Nival S, Thiriot A (1975) Influence des conditions hivernales sur les productions phyto- et zooplanctoniques en Méditerranée Nord-Occidentale. V. Biomasse et production zooplanctonique - relations phyto-zooplancton. Mar Biol 31:249-270

Orlóci L (1978) An agglomerative method for classification of plant communities. J Ecol 55:193-205

Owen RW (1981) Fronts and eddies in the sea: mechanisms, interactions and biological effects. In: Longhurst AR (ed) Analysis of marine ecosystems. Academic Press, Dartmouth, p 197-233

Prieur L, Copin-Montegut C, Claustre H (1993) Biophysical aspects of 'Almofront-1', an intensive study of a geostrophic frontal jet. A Inst océanogr, Monaco, Nouv Sér 69(1):71-86

Razouls C. Thiriot A (1973) Donnés quantitatives du mésozooplancton en Méditerranée occidentale (saisons hivernales 1966-1970). Vie Milieu 23 (2B):209-241

Scherrer B (1984) Biostatistique. G Morin, Chicoutini, Canada

Seguin G, Dallot S (1989) Repartition verticale des copépodes pélagiques durant la campagne 'Tomofront-88'. France JGOFS PFO, Compte rendue Table ronde FRONTAL, 13-15 Juin 1989, Brest. INSU, Paris

Shepard RN (1962) The analysis of proximities: multidimen-

This article was submitted to the editor sional scaling with an unknown distance function. Psychometrika 27:125-140

Sokal RR, Rohlf FJ (1981) Biometry. WH Freeman \& Co, New York

Sournia A, Brylinski JM, Dallot S, Corre PL, Leveau M, Prieur L, Froget C (1990) Fronts hydrologiques au large des côtes françaises: les sites-ateliers du programme Frontal. Oceanol Acta 13,4:413-438

Stocchino C, Testoni A (1978) Sulle caratteristiche idrologiche delle acque del Mar Ligure. Rep Ist Idrogr Mar Il 3066:1-18

Taupier-Letage I, Millot C (1986) General hydrodynamical features in the Ligurian Sea inferred from the DYOME experiment. Oceanol Acta 9(2):119-131

Tranter DJ, Parker RR, Cresswell GR (1980) Are warm-core eddies unproductive? Nature 284:540-542

Wald L (1985) Apport de la télédéctection spatiale en infraruge proche et moyen à la connaissance du milieau marin: relations entre le champ de température et le champ de courant, observations de l'état de surface et mesures de la vitesse du vent, la dynamique de la couche superficielle en Mer Ligure. Thèse Doct Etat, Universitê Toulon-Var

Williams DA (1976) Improved likelyhood ratio tests for complete contingency tables. Biometrika 63:33-37

Wright SP (1992) Adjusted p-values for simultaneous inference. Biometrics 48:1005-1013

Zunini-Sertorio T, Dagnino I, Vaccarezza C (1990) Distribution of macroplankton and marine circulation in the Ligurian Sea. Rapp P-v Réun Cons int Explor Mer 32(1): 219

Manuscript first received: December 27, 1994

Revised version accepted: April 11, 1995 